\title{
LANDASAN PENGEMBANGAN KURIKULUM
}

\author{
Oleh: Safaruddin
}

$$
* * *
$$

\begin{abstract}
Abstrak
Kurikukulm adalah inti dari pendidikan dimana kurikulum dapat diartikan sebagai seperangkat rencana dan pengaturan mengenai tujuan, isi dan bahan pelajaran serta cara yang digunakan sebagai pedoman penyelenggaraan kegiatan pembelajaran untuk mencapai tujuan pendidikan tertentu landasan pengembangan kurikulum dapat diartikan sebagai suatu gagasan, asumsi atau prinsip yang menjadi sandaran atau titik tolak dalam mengembangkan kurikulum. Adapun yang menjadi landasan dalam mengmbangkan sebuah kurikulum di antaranya: landasan religius, landasan filosofis (perenialisme, esensialisme, eksistensialisme, profresivisme, rekonstruktivisme), landasan yuridis, landasan psikologis, landasan sosiologis atau sosial budaya serta landasan organisatoris.
\end{abstract}

Kata Kunci : Landasan, Pengembangan, Kurikulum

\section{PENDAHULUAN}

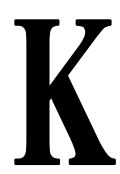

urikulum merupakan inti dari bidang pendidikan dan memiliki pengaruh terhadap seluruh kegiatan pendidikan. Mengingat pentingnya kurikulum dalam pendidikan dan kehidupan manusia, maka penyusunan kurikulum tidak dapat dilakukan secara sembarangan. Penyusunan kurikulum membutuhkan landasan-landasan yang kuat, yang didasarkan pada hasil-hasil pemikiran dan penelitian yang mendalam. Penyusunan kurikulum yang tidak didasarkan pada landasan yang kuat dapat berakibat fatal terhadap kegagalan pendidikan itu sendiri. Dengan sendirinya, akan berkibat pula terhadap kegagalan proses pengembangan manusia. Oleh karena itu kurikulum dalam pendidikan perlu mempunyai perhatian yang besar baik bagi pemerintah sebagai penanggung jawab umum atau pihak sekolah yang turun langsung

\footnotetext{
* Dosen Tetap STAI Muhammadiyah Sinjai
} 


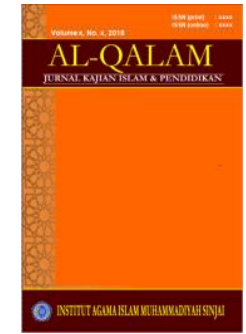

AL-QALAM

Jurnal Kajian Islam \& Pendidikan

Volume 07 No 022015

ISSN (print) : 1858-4152

ISSN (online) : 2715-5684

Homepage : http://journal.iaimsinjai.ac.id/index.php/al-qalam

mengimplementasikan kurikulum tersebut ke peserta didik, dengan berlandaskan pada filosofis, psikologis, sosiologis dan organisatoris serta bersifat dinamis agar tujuan pendidikan bisa tercapai sesuai dengan yang diharapkan.

\section{PEMBAHASAN}

\section{A. DASAR ATAU LANDASAN PENGEMBANGAN KURIKULUM}

Dasar berarti sesuatu yang menjadi tumpuan berfikir atau berpendapat ${ }^{1}$. Landasan berarti alas, dasar atau tumpuan ${ }^{2}$. Menurut Siregar dan Nara yang dikutip oleh Rahmat Raharjo mengatakan bahwa landasan adalah a). Sebuah pondasi yang diatasnya dibangun sebuah bangunan, b). Pikiran-pikiran abstrak yang dijadikan titik tolak atau titik berangkat bagi pelaksanaan suatu kegiatan, c). Pandangan-pandangan abstrak yang telah teruji, yang dipergunakan sebagai titik tolak dalam menyusun konsep, melaksanakan konsep, dan mengevaluasi konsep ${ }^{3}$

Istilah kurikulum muncul untuk pertama kalinya dan digunakan dalam bidang olahrang Secara etimologi curriculum yang berasal dari bahasa yunani, yaitu currir yang artinya "pelari” dan curere yang berarti "tempat berpacu". Jadi istilah kurikulum pada zaman Romawi Kuno mengandung pengertian sebagai suatu jarak yang harus ditempuh oleh pelari dari garis star sampai garis finish. Baru pada tahun 1855, istilah kurikulum dipakai dalam bidang pendidikan yang mengandung arti sejumlah mata pelajaran pada pergruruan tinggi ${ }^{4}$

Kurikulum adalah seperangkat rencana dan pengaturan mengenai tujuan, isi dan bahan pelajaran serta cara yang digunakan sebagai pedoman penyelenggaraan kegiatan pembelajaran untuk mencapai tujuan pendidikan tertentu ${ }^{5}$.

\section{${ }^{1}$ KBBI Of Line}

${ }^{2}$ Ibid

3 Rahmat Raharjo, Pengembangan dan Inovasi Kurikulum, (Yogyakarta: Baituna Publishing, 2012) hlm. 28.

${ }^{4}$ Sholeh Hidayat, Pengembangan Kurikulum Baru, (Bandung: PT Remaja Rosdakarya, 2013) hlm. 19

${ }^{5}$ Rusman, Manajemen Kurikulum, (Jakarta: PT Raja Grafindo Persada, 2009) hlm. 3 
Dalam pandangan klasik, kurikulum dipandang sebagai rancana pembelajaran di suatu sekolah atau madrasah, pelajaran-pelajaran apa yang harus ditempuh disekolah atau madrasah itulah kurikulum. Sementara dalam pandangan modern kurikulum lebih dianggap sebagai pengalaman atau sesuatu yang nyata terjadi dalam proses pendidikan. ${ }^{6}$

Menurut Undang-Undang Sistem Pendidikan Nasional Nomor 20 Tahun 2003 Pasal 1 ayat 19 : Kurikulum adalah seperangkat rencana dan pengaturan mengenai tujuan, isi dan bahan pelajaran serta cara yang digunakan sebagai pedoman penyelenggaraan kegiatan pembelajaran untuk mencapai tujuan pendidikan tertentu. ${ }^{7}$

Berdasarkan uraian diatas maka landasan pengembangan kurikulum dapat diartikan sebagai suatu gagasan, asumsi atau prinsip yang menjadi sandaran atau titik tolak dalam mengembangkan kurikulum dengan tetap mempertimbangkan landasan filosofi, landasan yuridis, landasan psikologis, landasan sosiologis, Landasan ilmu pengetahuan dan teknologi ${ }^{8}$. Beberapa ahli berpendapat tentang landasan kurikulum diantaranya Omar M. Al-Toumy yang dikutip oleh Muhammad Zein menyatakan bahwa dasar pengmbangan kurikulum menjadi empat yakni : dasar agama, psikologis falsafah, dan sosial $^{9}$ sementara menurut S. Nasution yang dikutip oleh Ahmad Janan menyatakan bahwa pengembangan kurikulum menjadi empat asas yakni : Asas Ffilosofis, sosiologis, psikologis dan organisatoris $^{10}$ Pada pengembangan kurikulum 2013 ini dilansasi secara filosifis, yuridis dan konseptual ${ }^{11}$

\section{Landasan Religius}

\footnotetext{
${ }^{6}$ Sholeh Hidayat, Pengembangan..., hlm. 20-21

${ }^{7}$ Undang-Undang Sistem Pendidikan Nasional No. 20 Tahun 2003

${ }^{8}$ Santoso, Dasar-Dasar Pengembangan Kurikulum, (Yogyakarta: IAIN Sunan Kalijaga, 1998), hlm.1.

${ }^{9}$ Muhammad Zein, Asas dan Pemgembangan Kurikulum, (Yogyakarta :Sumbangsih Offset, 1985), hlm. 21

${ }^{10}$ Ahmad Janan Asifuddin, Mengungkit Pilar-pilar Pendidikan Islam, (Jogjakarta ; SUKA Press, 2010), hlm. 114

${ }^{11}$ Mulyasa, Pengembangan dan Implementasi Kurikulum 2013, cet. Ke-4 (Bandung: PT Remaja Rosda Karya, 2014), hlm. 64
} 
Landasan religius dalam mengembangkan kurikulum artinya pengembangan dan penerapan kurikulum berdasarkan nilai-nilai ilahiyah sehingga dengan adanya dasar ini kurikulum diharapkan dapat membimbing peserta didik untuk mebina iman yag kuat, teguh terhadap ajaran agama, berkhlak mulia dan melengkapinya dengan ilmu pengetahuan yang bermanfaat di dunia dan di akhirat ${ }^{12}$

Landasan religius ini relevan dengan tujuan Pendidikan Nasional sebagaiman yang termaktub dalan Undang-Undang Sistem Pendidikan Nasional Nomor 20 Tahun 2003 yakni Pendikan Nasional bertujuan mengembangkan potensi peserta didik agar menjadi manusia yang beriman dan bertakwa kepada Tuhan Yang Maha Esa, berakhlak mulia, berilmu, cakap, kreatif, mandiri, dan menjadi warga negara yang demokratis serta bertanggungjawab ${ }^{13}$

\section{Landasan Folosofis}

Filsafat memegang peranan penting dalam pengembangan kuikulum. Sama halnya seperti dalam Filsafat Pendidikan, kita dikenalkan pada berbagai aliran filsafat, seperti : perenialisme, essensialisme, eksistesialisme, progresivisme, dan rekonstruktivisme. Dalam pengembangan kurikulum pun senantiasa berpijak pada aliran - aliran filsafat tertentu, sehingga akan mewarnai terhadap konsep dan implementasi kurikulum yang dikembangkan, Di bawah ini diuraikan tentang isi dari-dari masing-masing aliran filsafat, kaitannya dengan pengembangan kurikulum. ${ }^{14}$

a. Perenialisme lebih menekankan pada keabadian, keidealan, kebenaran dan keindahan dari pada warisan budaya dan dampak sosial tertentu. Pengetahuan dianggap lebih penting dan kurang memperhatikan kegiatan sehari-hari. Pendidikan yang menganut faham ini menekankan pada

\footnotetext{
${ }^{12}$ Sholeh Hidayat, Pengembangan..., hlm. 34

${ }^{13}$ Undang-Undang Sistem Pendidikan Nasional No. 20 Tahun 2003

${ }^{14}$ http://geo.fis.unesa.ac.id/web/index.php/en/kajian-kurikulum/108-landasan-kurikulum di akses tanggal 26 Februari 2015
} 
kebenaran absolut, kebenaran universal yang tidak terikat pada tempat dan waktu. Aliran ini lebih berorientasi ke masa lalu.

b. Essensialisme menekankan pentingnya pewarisan budaya dan pemberian pengetahuan dan keterampilan pada peserta didik agar dapat menjadi anggota masyarakat yang berguna. Matematika, sains dan mata pelajaran lainnya dianggap sebagai dasar-dasar substansi kurikulum yang berharga untuk hidup di masyarakat. Kehidupan masyarakat dapat ditingkatkan dan diperbaiki dengan pertolongan ilmu pengetahuan karenan peranan ilmu pengetahuan bagi masyarakat dapat mengembangkan masyarakat menjadi berbudaya ${ }^{15}$ Sama halnya dengan perenialisme, essesialisme juga lebih berorientasi pada masa lalu.

c. Eksistensialisme menekankan pada individu sebagai sumber pengetahuan tentang hidup dan makna. Untuk memahami kehidupan seseorang mesti memahami dirinya sendiri. Aliran ini mempertanyakan : bagaimana saya hidup di dunia ? Apa pengalaman itu ?

d. Progresivisme menekankan pada pentingnya melayani perbedaan individual, berpusat pada peserta didik, variasi pengalaman belajar dan proses. Progresivisme merupakan landasan bagi pengembangan belajar peserta didik aktif. Konsep yang didasari oleh pengetauan dan kepercayaan bahwa manusia itu mempunyai kemampuan-kemampuan yang wajar dan dapat menghadapi serta mengatasi masalah-masalah yang bersifat menekan atau mencancam adanya manusia itu sendiri ${ }^{16}$

e. Rekonstruktivisme merupakan elaborasi lanjut dari aliran progresivisme. Pada rekonstruktivisme, peradaban manusia masa depan sangat ditekankan. Di samping menekankan tentang perbedaan individual seperti pada progresivisme, rekonstruktivisme lebih jauh menekankan tentang pemecahan masalah, berfikir kritis dan sejenisnya. Aliran ini akan mempertanyakan untuk apa berfikir kritis, memecahkan masalah, dan

${ }^{15}$ Iskandar Wiryokusumo dan Usman Mulyadi, Dasar-dasar Pengembangan Kurikulum, (Jakarta : PT. Bina Aksara, 1988), hlm. 70

${ }^{16}$ Ibid, hlm. 68 


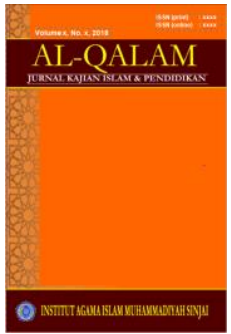

AL-QALAM

Jurnal Kajian Islam \& Pendidikan

Volume 07 No 022015

ISSN (print) : 1858-4152

ISSN (online) : 2715-5684

Homepage : http://journal.iaimsinjai.ac.id/index.php/al-qalam

melakukan sesuatu ? Penganut aliran ini menekankan pada hasil belajar dari pada proses.

Dalam pendekatan filosofi pengembangan kurikulum di Negara Indonesia harus mengacu pada visi, misi dan tujuan Pendidikan Nasional, sehingga tidak bertentangan dengan falsafah negara yaitu Pancasila. ${ }^{17}$ karena Pancasila merupakan dasar Negara, pandangan hidup (way of lofe), dan sekaligus menjadi ideologi bangsa dan negara indonesia.

Landasan filsafat dalam pengembangan kurikulum memilki empat fungsi yaitu :

a. Filsafat dapat menentukan arah dan tujuan pendidikan

b. Filsafat dapat menentukan isi atau materi pelajaran yang harus dipelajari

c. Filsafat dapat menentukan strategi atau cara pencapaian tujuan

d. Filsafat dapat menentukan tolak ukur keberhasilan proses pendidikan ${ }^{18}$

\section{Landasan Yuridis}

Setiap Pendidikan formal sudah dipastikan akan dikelola oleh badan hukum sesuai dengan peraturan yang ditetapkan, termasuk kurikulum yang digunakan. Oleh karena itu, pengembangan kurikulum yang dilakukan harus mengacu pada landasan yuridis yang telah ditetapkan ${ }^{19}$

Dalam pengembangan kurikulum landasan yuridis yakni berupa aturanaturan yang telah ditetapkan oleh pemerintah baik itu berupa Peraturan Pemerintah, Peraturan Menteri Agama maupun Peraturan Menteri Pendidikan dan Kebudayaan yang terkait dengan pendidikan. Mengenai landasan yuridis dalam pengembangan kurikulum dapat dilihat secara rinci pada lampiran makalah ini

\section{Landasan Psikologis}

Psikologi adalah ilmu yang mempelajari tingkah laku manusia, sedangkan kurikulum adalah upaya menentukan program pendidikan untuk mengubah

\footnotetext{
${ }^{17}$ Undang-Undang No. 20 Tahun 2013 Tentang Sistem Pendidikan Nasional

${ }^{18}$ Sholeh Hidayat, Pengembangan..., hlm. 35

${ }^{19}$ Rahmat Raharjo, Pengembangan... hlm. 29.
} 
prilaku manusia. Oleh karena itu, pengembangan kurikulum harus berdasarkan psikologi sebagai acuan dalam menentukan apa dan bagiamana prilaku itu dikembangkan, seperti perkembangan fisik, intelektual, sosial, dan moral. Perbedaan psikologis dari masing-masing individu dalam kegiatan pembelajaran juga mendasari arah dan isi dalam pengembangan kurikulum. Landasan ini bertujuan untuk menyesuaikan masing-masing perbedaan secara psikologis dari materi dan isi kurikulum yang dikembangkan ${ }^{20}$

Dalam pengembangan kurikulum ada dua cabang psikologi yang perlu diperhatikan yakni psikologi belajar dan psikologi perkembangan. Psikologi perkembangan diperlukan dalam menentukan isi kurikulum yang diberikan kepada peserta didikagar tingkat keluasan dan kedalaman materi/bahan ajar sesuai dengan taraf perkembangan peserta didik. Psikologi belajar berkenan dengan bagaimana kurikulum itu diimplementasikan kepada peserta didik, dan bagaimana pula peserta didik harus mempelajarinya agar pembelajaran mencapai tujuan yang diharapkan ${ }^{21}$ Sholeh hidayat lebih lanjut menambahkan bahwa ruang lingkup isi kurikulum pada suatu jenjang atau tingkat tertentu berbeda-beda dengan demikian terdapat hubungan yang erat antara kurikulum dengan psikologi belajar dan psikologi perkembangan anak. ${ }^{22}$

\section{Landasan Sosiologis atau Sosial-Budaya}

Perbedaan sosial budaya dalam masyarakat yang berbeda, yang beragam dan bervariasi menjadikan pengembangan kurikulum harus disesuikan dengan kondisi yang ada. Landasan sosial budaya dalam pengembangan kurikulum bertujuan untuk menyesuaikan masing-masing perbedaan, baik dari segi sosial maupun dari segi budaya dan kultur yang ada dimasyarakat sehingga akan terjalin keseimbangan dalam kegiatan pembelajaran ${ }^{23}$

\footnotetext{
${ }^{20}$ Ibid, hlm. 30-31

${ }^{21}$ Hermawan dkk, Pengembangan Kurikulum dan Pembelajaran, (Jakarta : Universitas Terbuka, 2008), hlm. 29.

${ }^{22}$ Sholeh Hidayat, Pengembangan..., hlm. 36

${ }^{23}$ Rahmat Raharjo, Pengembangan... hlm. 31
} 


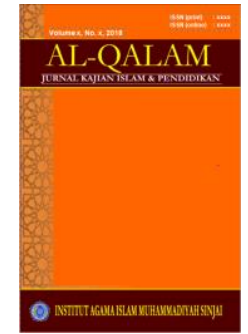

AL-QALAM

Jurnal Kajian Islam \& Pendidikan

Volume 07 No 022015

ISSN (print) : 1858-4152

ISSN (online) : 2715-5684

Homepage : http://journal.iaimsinjai.ac.id/index.php/al-qalam

Asas sosiologi mempunyai peranan penting dalam dalam mengembangkan kurikulum pendidikan pada masyarakat dan bagsa di muka bumi ini krena suatu kurikulum prinsipnya mencerminkan keinginan, cita-cita tertentu dan dan kebutuhan masyarakat ${ }^{24}$. Sehingga lembaga pendidikan harus relevan dan berusaha menjawab serta memenuhi kebutuhan peserta didik, utamanya terkai masa depan mereka ditengah dinamika masyarakat dan dunia kerja ${ }^{25}$. Selain itu masyarakat mempunyai norma-norma, adat kebiasaan yang mau tidak mau harus dikenal dan diwujudkan peserta didik dalam prilkunya karena peserta didik pada gilirannya harus hidup dalam masyarakat itu maka masyarakat harus dijadikan suatu faktor yang harus dipertimbangkan dalam pembinaan dan pengembangan kurikulum $^{26}$

\section{Landasan Ilmu Pengetahuan dan Teknologi}

Ilmu pengetahuan adalah seperangkat pengetahuan yang disusun secara sistematis yang dihasilkan melalui penelitian ilmiah sedangkan teknologi adalah aplikasi dari ilmu pengetahuan untuk memecahkan masalah-masalah praktis dalam kehidupan ${ }^{27}$

Ilmu pengetahuan dan teknologi pada hakikatnya adalah hasil kebuadayaan manusia yang berkembang dengan pesat seiring dengan lajunya perkembangan masyarakat. Teknologi merupakan aplikasi dari ilmu pengetahuan dan ilmu-ilmu lainya yang berfungsi untuk memecahkan masalah-masalah praktis. Perkembangan ilmu pengetahuan di dunia ini semakin pesat berkembang serta arus transformasi ilmu teknologi yang tak mungkin terelakkan lagi, menjadikan kurikulum pendidikan harus disesuikan dengan kondisi modern sekaran ini. ${ }^{28}$

Perkembangan IPTEK terutama dalam bidang transportasi dan komunikasi telah mengubah tatanan kehidupan manusia Kegiatan pendidikan membutuhkan

${ }^{24}$ Abdullah Idi, Pengembangan Kurikulum Teori dan Praktek, Cet. Ke-3 (Jogjakarta: ArRuzz Media, 2010), hlm. 75

${ }^{25}$ Ahmad Janan Asifuddin, Mengungkit Pilar-Pilar ...., hlm. 115

${ }^{26}$ Sholeh Hidayat, Pengembangan..., hlm. 40

${ }^{27} \mathrm{Ibid}$, hlm. 48

${ }^{28}$ Rahmat Raharjo, Pengembangan... hlm. 32 
media produk teknologi dalam menujang pendidikah sehingga perkembangan IPTEK menjadi salah satu landasan pengembangan kurikulum

\section{Landasan Organisatoris}

Landasan in berkenan dengan pengorganisasian materi yakni acuan ruang lingkup materi dan perurtan masing-masing materi serta materi sebagai keseluruhan disusun dan di atus secara sistematis sesuai dengan fase-fase pertumbuhan dan perkembangan fisik-psikis peserta didik berdasarkan pemikiran yang mendalam dan cukup komprenhensif. ${ }^{29}$ Kemudian yang tak kalah pentingnya adalah tentang pengorganisasian bahan ajar seperti pengorganisasin berdasarkan : topik, tema, kronolgi, konsep, isu, logika dan proses disiplin ${ }^{30}$

Pengorganisasin kurikulum memiliki tiga tipe,${ }^{31}$ memperhatikan tiga hal dan memilki tiga kecenderungan ${ }^{32}$

\begin{tabular}{|c|c|c|}
\hline $\begin{array}{c}\text { Tipe Kurikulum } \\
\text { (Menurut Sholeh } \\
\text { Hidayat) }\end{array}$ & $\begin{array}{c}\text { Hal-hal yang perlu } \\
\text { diperhatikan dalam } \\
\text { pengorganisasian } \\
\text { kurikulm }\end{array}$ & $\begin{array}{l}\text { Kecenderungan yang } \\
\text { harus diperhatikan dalam } \\
\text { pengornaginasasin } \\
\text { kurikulum }\end{array}$ \\
\hline $\begin{array}{l}\text { 1. Kurikulum dengan } \\
\text { pendekatan mata } \\
\text { pelajaran } \\
\text { 2. Kurikulum korelasi } \\
\text { 3. Kurikulum } \\
\text { integrasi }\end{array}$ & $\begin{array}{ll}\text { 1. } & \text { Tujuan bahan } \\
\text { pelajaran } \\
\text { 2. } \\
\text { Sasaran beban } \\
\text { pelajaran } \\
\text { 3. } \begin{array}{l}\text { Pengorganisasian } \\
\text { bahan }\end{array}\end{array}$ & $\begin{array}{l}\text { 1. Kekinian } \\
\text { 2. Kemas-depanan } \\
\text { 3. Kepentingan satuan } \\
\text { pendidikan }\end{array}$ \\
\hline
\end{tabular}

\section{B. LANDASAN PENGEMBANGAN KURIKULUM 2013}

\section{Landasan Filosofis}

Landasan filosofis dalam pengembangan kurikulum menentukan kualitas peserta didik yang akan dicapai kurikulum, sumber dan isi kurikulum,

\footnotetext{
${ }^{29}$ Ahmad Janan Asifuddin, Mengungkit..., hlm. 116

${ }^{30}$ Adullah Idi, Pengembangan ..., hlm. 94

${ }^{31}$ Sholeh Hidayat, Pengembanga Kurikulum,... hlm. 41-45

${ }^{32}$ Adullah Idi, Pengembangan ..., hlm. 94
} 


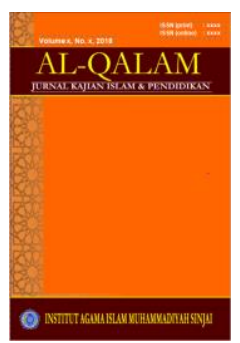

AL-QALAM

Jurnal Kajian Islam \& Pendidikan

Volume 07 No 022015

ISSN (print) : 1858-4152

ISSN (online) : 2715-5684

Homepage : http://journal.iaimsinjai.ac.id/index.php/al-qalam

proses pembelajaran, posisi peserta didik, penilaian hasil belajar, hubungan peserta didik dengan masyarakat dan lingkungan alam sekitar ${ }^{33}$

Kurikulum 2013 Mata Pelajaran PAI dan Bahasa Arab dikembangkan dengan landasan filosofis yang memberikan dasar bagi pengembangan seluruh potensi peserta didik menjadi manusia Indonesia berkualitas yang tercamtum dalam tujuan Pendidikan Nasional

Pada dasarnya tidak ada satupun filosofi pendidikan yang dapat digunakan secara spesifik untuk pengembangan kurikulum yang dapat menghasilkan manusia yang berkualitas berdasarkan hal tersebut, kurikulum 2013 dikembangkan dengan menggunakan filosofi sebagai berikut : ${ }^{34}$

a. Pendidikan berakar pada budaya bangsa untuk membangun kehidupan bangsa masa kini dan masa mendatang. Pandangan ini menjadikan Kurikulum 2013 dikembangkan berdasarkan budaya bangsa Indonesia yang beragam, diarahkan untuk membangun kehidupan masa kini, dan untuk membangun dasar bagi kehidupan bangsa yang lebih baik di masa depan. Mempersiapkan peserta didik untuk kehidupan masa depan selalu menjadi kepedulian kurikulum, hal ini mengandung makna bahwa kurikulum adalah rancangan pendidikan untuk mempersiapkan kehidupan generasi muda bangsa. Dengan demikian, tugas mempersiapkan generasi muda bangsa menjadi tugas utama suatu kurikulum. Untuk mempersiapkan kehidupan masa kini dan masa depan peserta didik, Kurikulum 2013 mengembangkan pengalaman belajar yang memberikan kesempatan luas bagi peserta didik untuk menguasai kompetensi yang diperlukan bagi kehidupan di masa kini dan masa depan, dan pada waktu bersamaan tetap mengembangkan kemampuan mereka sebagai pewaris budaya bangsa dan orang yang peduli terhadap permasalahan masyarakat dan bangsa masa kini.

\footnotetext{
${ }^{33}$ Permenag No. 912 Tahun 2013 Tentang Kurikulum Madrasah 2013 Mata Pelajaran PAI dan Bahasa Arab

${ }^{34}$ Permenag No. 912 Tahun 2013 Tentang Kurikulum Madrasah 2013 Mata Pelajaran PAI dan Bahasa Arab
} 
b. Peserta didik adalah pewaris budaya bangsa yang kreatif. Menurut pandangan filosofi ini, prestasi bangsa di berbagai bidang kehidupan di masa lampau adalah sesuatu yang harus termuat dalam isi kurikulum untuk dipelajari peserta didik. Proses pendidikan adalah suatu proses yang memberi kesempatan kepada peserta didik untuk mengembangkan potensi dirinya menjadi kemampuan berpikir rasional dan kecemerlangan akademik dengan memberikan makna terhadap apa yang dilihat, didengar, dibaca, dipelajari dari warisan budaya berdasarkan makna yang ditentukan oleh lensa budayanya dan sesuai dengan tingkat kematangan psikologis serta kematangan fisik peserta didik. Selain mengembangkan kemampuan berpikir rasional dan cemerlang dalam akademik, Kurikulum 2013 memposisikan keunggulan budaya tersebut dipelajari untuk menimbulkan rasa bangga, diaplikasikan dan dimanifestasikan dalam kehidupan pribadi, dalam interaksi sosial di masyarakat sekitarnya, dan dalam kehidupan berbangsa masa kini.

c. Pendidikan ditujukan untuk mengembangkan kecerdasan intelektual dan kecemerlangan akademik melalui pendidikan disiplin ilmu. Filosofi ini menentukan bahwa isi kurikulum adalah disiplin ilmu dan pembelajaran adalah pembelajaran disiplin ilmu (essentialism). Filosofi ini mewajibkan kurikulum memiliki nama matapelajaran yang sama dengan nama disiplin ilmu, selalu bertujuan untuk mengembangkan kemampuan intelektual dan kecemerlangan akademik.

d. Pendidikan untuk membangun kehidupan masa kini dan masa depan yang lebih baik dari masa lalu dengan berbagai kemampuan intelektual, kemampuan berkomunikasi, sikap sosial, kepedulian, dan berpartisipasi untuk membangun kehidupan masyarakat dan bangsa yang lebih baik (experimentalism and social reconstructivism). Dengan filosofi ini, Kurikulum 2013 bermaksud untuk mengembangkan potensi peserta didik menjadi kemampuan dalam berpikir reflektif bagi penyelesaian masalah 


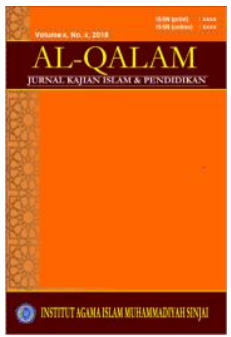

AL-QALAM

Jurnal Kajian Islam \& Pendidikan

Volume 07 No 022015

ISSN (print) : 1858-4152

ISSN (online) : 2715-5684

Homepage : http://journal.iaimsinjai.ac.id/index.php/al-qalam

sosial di masyarakat, dan untuk membangun kehidupan masyarakat demokratis yang lebih baik.

Dengan demikian, Kurikulum 2013 menggunakan filosofi sebagaimana di atas dalam mengembangkan kehidupan individu peserta didik dalam beragama, seni, kreativitas, berkomunikasi, nilai dan berbagai dimensi inteligensi yang sesuai dengan diri seorang peserta didik dan diperlukan masyarakat, bangsa dan ummat manusia.

\section{Landasan yuridis}

Landasan Yuridis pengembangan KTSP dan Kurikulum 2013 dapat dilihat pada tabel berikut :

\begin{tabular}{|c|c|c|}
\hline Landasan Yuridis & KTSP & Kurikulum 2013 \\
\hline \multirow[t]{2}{*}{ Undang-Undang } & \multicolumn{2}{|l|}{ UUD 1945} \\
\hline & \multicolumn{2}{|c|}{ Undang-Undang No 20 Tahun 2003} \\
\hline \multirow{2}{*}{$\begin{array}{l}\text { Peraturan } \\
\text { Pemerintah }\end{array}$} & \multirow{2}{*}{ PP No. 19 Thn 2005} & PP No. 19 Thn 2005 \\
\hline & & PP No. 32 Thn 20013 \\
\hline 3. RPJMN & & RPJMN 2014 \\
\hline 4. INPRES & & $\begin{array}{l}\text { INPRES No } 11 \text { Tahun } \\
2010\end{array}$ \\
\hline \multicolumn{3}{|c|}{ SNP } \\
\hline Standar isi & $\begin{array}{l}\text { Permendiknas No. } 22 \\
\text { Tahun } 2006\end{array}$ & $\begin{array}{l}\text { Permendikbud No. } 64 \\
\text { Tahun } 2013\end{array}$ \\
\hline Standar Proses & $\begin{array}{l}\text { Permendiknas No. } 41 \\
\text { Tahun } 2007\end{array}$ & $\begin{array}{l}\text { Permendikbud No. } 65 \\
\text { tahun } 2013\end{array}$ \\
\hline $\begin{array}{l}\text { Standar kompetensi } \\
\text { Lulusan }\end{array}$ & $\begin{array}{l}\text { Permendiknas No. } 23 \\
\text { Tahun } 2006\end{array}$ & $\begin{array}{l}\text { Permendikbud No } 54 \\
\text { tahun } 2013\end{array}$ \\
\hline \multirow{2}{*}{$\begin{array}{l}\text { Standar Tenaga } \\
\text { Pendidik dan Tenaga } \\
\text { kependidikan }\end{array}$} & $\begin{array}{l}\text { Permendiknas No. } 12 \\
\text { Tahun } 2007\end{array}$ & $\begin{array}{l}\text { Permendiknas No. } 12 \\
\text { Tahun } 2007\end{array}$ \\
\hline & $\begin{array}{l}\text { Permendiknas No. } 13 \\
\text { Tahun } 2007\end{array}$ & $\begin{array}{l}\text { Permendiknas No. } 13 \\
\text { Tahun } 2007\end{array}$ \\
\hline
\end{tabular}


Homepage : $\underline{\text { http://journal.iaimsinjai.ac.id/index.php/al-qalam }}$

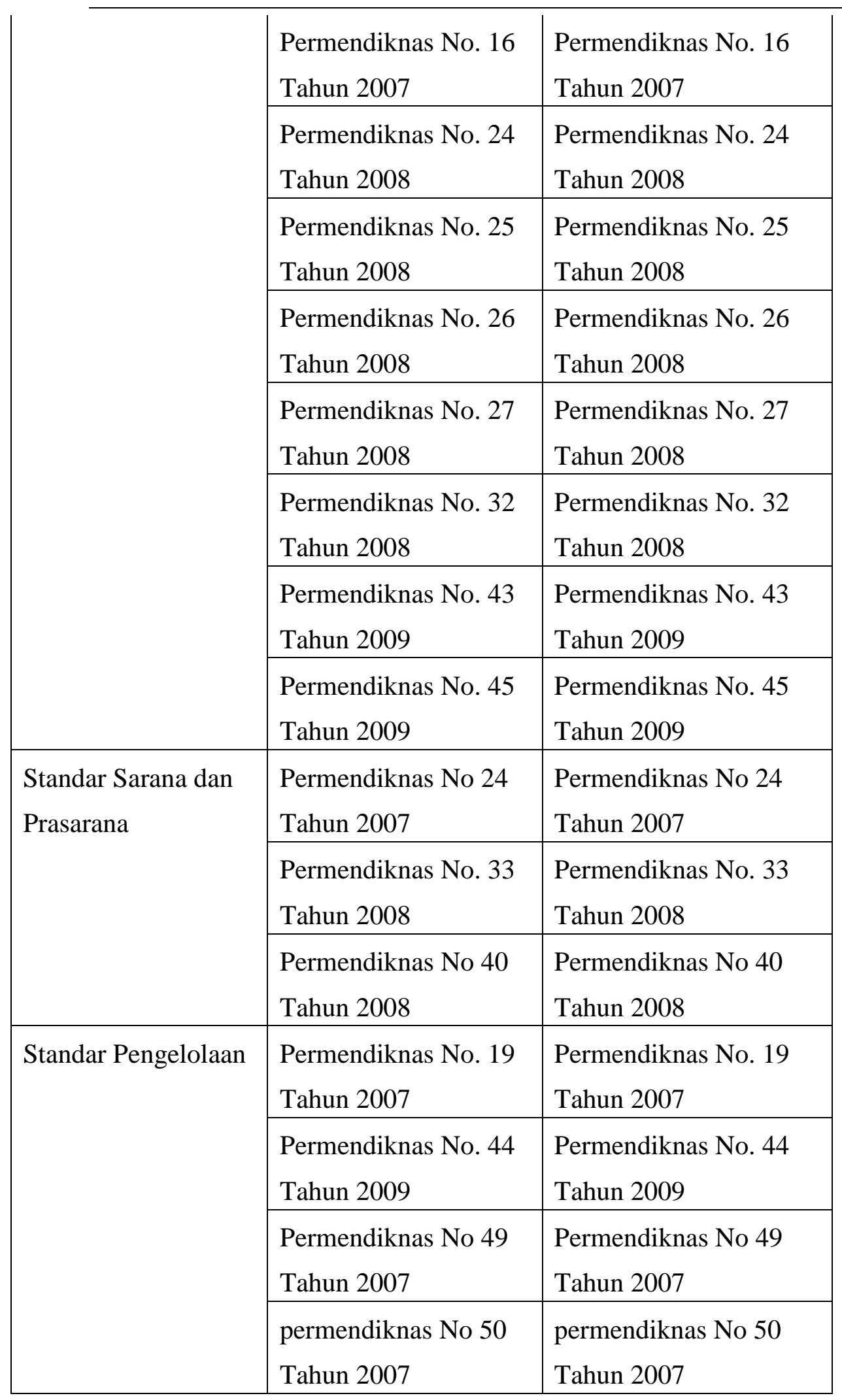




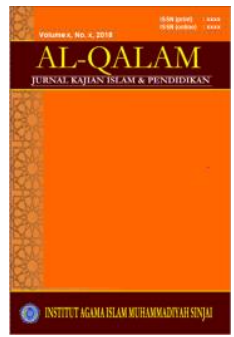

AL-QALAM

Jurnall Kajian Islam \& Pendidikan

Volume 07 No 022015

ISSN (print) : 1858-4152

ISSN (online) : 2715-5684

Homepage : http://journal.iaimsinjai.ac.id/index.php/al-qalam

\begin{tabular}{|c|c|c|}
\hline Standar Pembiayaan & $\begin{array}{l}\text { Permendiknas No } 69 \\
\text { Tahun } 2009\end{array}$ & $\begin{array}{l}\text { Permendiknas No } 69 \\
\text { Tahun } 2009\end{array}$ \\
\hline \multirow[t]{2}{*}{ Standar Penilaian } & \multirow[t]{2}{*}{$\begin{array}{l}\text { Permendiknas No } 20 \\
\text { Tahun } 2007\end{array}$} & $\begin{array}{l}\text { Permendikbud No } 66 \\
\text { Tahun } 2013\end{array}$ \\
\hline & & $\begin{array}{l}\text { Permendikbud No } 104 \\
\text { Tahun } 2014\end{array}$ \\
\hline \multirow{3}{*}{$\begin{array}{l}\text { Permenag, KMA } \\
\text { dan Kep. Dirjen } \\
\text { Pendis }\end{array}$} & \multirow[t]{3}{*}{$\begin{array}{l}\text { Permenag No } 2 \text { Tahun } \\
2008\end{array}$} & $\begin{array}{l}\text { KMA No } 165 \text { Tahun } \\
2014\end{array}$ \\
\hline & & $\begin{array}{l}\text { KMA No } 207 \text { tahun } \\
2014\end{array}$ \\
\hline & & $\begin{array}{l}\text { Keputusan dirjen } \\
\text { PENDIS No } 481 \text { Tahun } \\
2015\end{array}$ \\
\hline \multirow[t]{4}{*}{ Permen yang lain } & & $\begin{array}{l}\text { Permendikbud No } 81 \mathrm{~A} \\
\text { Tahun } 2013\end{array}$ \\
\hline & & $\begin{array}{l}\text { Permendikbud No } 67 \\
\text { tahun } 2013\end{array}$ \\
\hline & & $\begin{array}{l}\text { Permendikbud No } 103 \\
\text { Tahun } 2014\end{array}$ \\
\hline & & $\begin{array}{l}\text { Permendikbud No } 105 \\
\text { Tahun } 2014\end{array}$ \\
\hline
\end{tabular}

Data diolah dari berbagai sumber

\section{Landasan Teoritis}

Kurikulum 2013 dikembangkan atas teori "pendidikan berdasarkan standar" (standard-based education), dan teori kurikulum berbasis kompetensi (competency-based curriculum). Pendidikan berdasarkan standar menetapkan adanya standar nasional sebagai kualitas minimal warganegara yang dirinci menjadi standar isi, standar proses, standar kompetensi lulusan, standar pendidik dan tenaga kependidikan, standar 


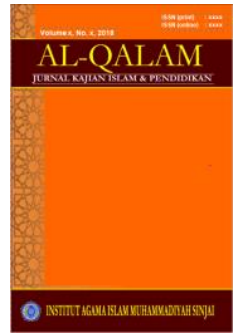

\section{AL-QALAM}

Jurmal Kajian Islam \& Pendidikan

Volume 07 No 022015

ISSN (print) : 1858-4152

ISSN (online) : 2715-5684

Homepage : $\underline{\text { http://journal.iaimsinjai.ac.id/index.php/al-qalam }}$

sarana dan prasarana, standar pengelolaan, standar pembiayaan, dan standar penilaian pendidikan. Kurikulum berbasis kompetensi dirancang untuk memberikan pengalaman belajar seluas-luasnya bagi peserta didik dalam mengembangkan kemampuan untuk bersikap, berpengetahuan, berketerampilan, dan bertindak.

Kurikulum 2013 menganut: (1) pembelajaran yang dilakukan guru (taught curriculum) dalam bentuk proses yang dikembangkan berupa kegiatan pembelajaran di sekolah, kelas, dan masyarakat; dan (2) pengalaman belajar langsung peserta didik (learned-curriculum) sesuai dengan latar belakang, karakteristik, dan kemampuan awal peserta didik. Pengalaman belajar langsung individual peserta didik menjadi hasil belajar bagi dirinya, sedangkan hasil belajar seluruh peserta didik menjadi hasil kurikulum. 


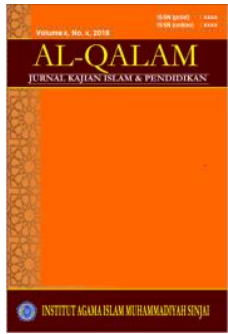

AL-QALAM

Jurnal Kajian Islam \& Pendidikan

Volume 07 No 022015

ISSN (print) : 1858-4152

ISSN (online) : 2715-5684

Homepage : http://journal.iaimsinjai.ac.id/index.php/al-qalam

\section{DAFTAR PUSTAKA}

Asifuddin, Ahmad Janan, Mengungkit Pilar-pilar Pendidikan Islam, Jogjakarta ; SUKA Press, 2010

Hermawan dkk, Pengembangan Kurikulum dan Pembelajaran, Jakarta : Universitas Terbuka, 2008

Hidayat, Sholeh, Pengembangan Kurikulum Baru, Bandung: PT Remaja Rosdakarya, 2013

Idi, Abdullah, Pengembangan Kurikulum Teori dan Praktek, Jogjakarta: Ar-Ruzz Media, 2010

KBBI Of Line

Mulyadi, Iskandar Wiryokusumo dan Usman Dasar-dasar Pengembangan Kurikulum, Jakarta : PT. Bina Aksara, 1988

Mulyasa, Pengembangan dan Implementasi Kurikulum 2013, Bandung: PT Remaja Rosda Karya, 2014

Permenag No. 912 Tahun 2013 Tentang Kurikulum Madrasah 2013 Mata Pelajaran PAI dan Bahasa Arab

Raharjo, Rahmat, Pengembangan dan Inovasi Kurikulum, Yogyakarta: Baituna Publishing, 2012

Rusman, Manajemen Kurikulum, Jakarta: PT Raja Grafindo Persada, 2009

Santoso, Dasar-Dasar Pengembangan Kurikulum, Yogyakarta: IAIN Sunan Kalijaga, 1998

Undang-Undang Sistem Pendidikan Nasional No. 20 Tahun 2003

Zein, Muhammad, Asas dan Pemgembangan Kurikulum, Yogyakarta :Sumbangsih Offset, 1985

http://geo.fis.unesa.ac.id/web/index.php/en/kajian-kurikulum/108-landasankurikulum di akses tanggal 26 Februari 2015

Undang-Undang Sistem Pendidikan Nasional No. 20 Tahun 2003

Peraturan Pemerintah No. 32 Tahun 2013 Tentang Standar Nasional Pendidikan

Keputusan Menteri Agama Republik Indonesia Tahun 2014 Tentang Implementasi Kurikulum di Madrasah

Permenag No.000912 Tahun 2013 Tentang Kurikulum Madrasah 2013 Mata Pelajaran Pendidikan Agama Islam dan Bahasa Arab

Permendikbud No. 54 Tahun 2013 Tentang Standar Kompetensi Lulusan 


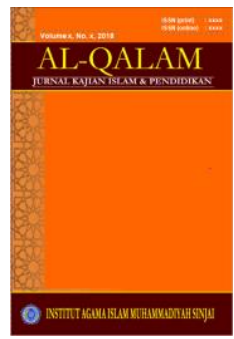

\section{AL-QALAM}

Jurmal Kajian Islam \& Pendidikan

Volume 07 No 022015

ISSN (print) : 1858-4152

ISSN (online) : 2715-5684

Homepage : $\underline{\text { http://journal.iaimsinjai.ac.id/index.php/al-qalam }}$

Permendikbud No. 64 Tahun 2013 Tentang Standar Isi

Permendikbud No. 65 Tahun 2013 Tentang Standar Proses

Permendikbud No. 66 Tentang Standar Penilaian

Permendikbud No. 67 Tentang Kerangka Dasar dan Struktur Kurikulum SD/MI

Permendikbud No. 81A Tahun 2103 Tentang Implementasi Kurikulum

Permendikbud No. 103 Tahun 2104 Tentang Pembelajaran Pada Pendidikan Dasar dan Menengah

Permendikbud No 104 tahun 2014 Tentang Standar Penilaian 